\title{
Radical Scavenging, Proteases Activities, and Phenolics Composition of Bark Extracts from 21 Medicinal Plants
}

\author{
Muhammad Asam Raza, ${ }^{1,2}$ Durre Shahwar, ${ }^{1}$ and Tania Khan ${ }^{1}$ \\ ${ }^{1}$ Center for Natural Product Drug Development, Department of Chemistry, Government College University, Lahore 54000, Pakistan \\ ${ }^{2}$ Natural Product Lab, Department of Chemistry, University of Gujrat, Gujrat, Pakistan
}

Correspondence should be addressed to Muhammad Asam Raza; asamgcu@yahoo.com

Received 31 October 2014; Revised 7 January 2015; Accepted 6 February 2015

Academic Editor: Alberto Ritieni

Copyright (C) 2015 Muhammad Asam Raza et al. This is an open access article distributed under the Creative Commons Attribution License, which permits unrestricted use, distribution, and reproduction in any medium, provided the original work is properly cited.

\begin{abstract}
Stem barks derived from twenty-one medicinal plants were extracted in methanol (100\%) and acetone-water (70:30 v/v) and at room as well as at reflux temperature conditions. Total phenolic contents, determined using FC (Folin Ciocalteu) reagent, ranged from 528 to $715 \mathrm{mg}$ GAE/g of crude extract. 15 out of 21 plants showed DPPH activity more than $90 \%$ and the rest of plants exhibited the activity in the range of $87-89 \%$. The methanolic extract of $P$. granatum obtained at room temperature showed the highest antiradical activity $(96 \%)$. The extracts with similar \% radical scavenging of $\mathrm{DPPH}^{\bullet}$ showed significant variation in $\mathrm{EC}_{50}$ value. Radical scavenging activity of E. rostrata, M. champaca, A. modesta, P. roxburghii, P. longifolia, E. suberosa, and $F$. infectoria was evaluated for the first time. A strong correlation between total phenols and antiradical activity was exhibited with $R$ values ranging from 0.7580 to 0.8874 indicating a linear relationship The extracts phenolic composition was studied by HPLC. All extracts showed remarkable antioxidant activity ( 87 to $96 \%$ ) while moderate activity was exhibited against protease (22 to 56\%). Gallic acid, tannic acid, quercetin, rutin, catechin, hesperidin, and cinnamic acid were identified as the major phenolic acids in the extracts of selected medicinal plants.
\end{abstract}

\section{Introduction}

The human body may produce oxygen-centered free radicals and other reactive oxygen species as by-products during physiological and biochemical processes. Overproduction of such free radicals causes oxidative damage to biomolecule (e.g., lipid, protein, and DNA) leading to chronic diseases, for example, cancer, arthritis, atherosclerosis, Alzheimer's disease, and diabetes $[1,2]$. On the other hand, lipid peroxidation is one of the main reasons for deterioration in food products.

Synthetic antioxidants such as BHT, BHA, TBHQ, and PG are usually used to overcome this problem. Most of these synthetic antioxidants are found to have toxic and carcinogenic effects on human health [3]. Several reports [4-6] reveal that natural compounds are capable of protecting against reactive oxygen species (ROS) mediated damage. Therefore, natural compounds may have potential application in prevention and curing of diseases [7].

The antioxidant constituents of plants are gaining the interest of scientists and food manufactures because the future demand is functional food with specific health effects. The antioxidant property of plant extracts has been attributed to their polyphenol contents. They improve the defensive system of plants against infection and injury. They are usually found as glycosylated derivatives or as salt with inorganic sulfates or organic acids [8]. They play a key role as antioxidants due to the presence of hydroxyl constituents and their aromatic nature which enable them to act as reducing agents, hydrogen donors, and singlet oxygen quenchers. In addition, they have a metal chelation potential [9].

To assess radicals scavenging ability, different in vitro methods have been used such as ABTS [10], DPPH [11], and DMPA [12]. Although these assays do not reproduce in vivo conditions but are useful to rank antioxidant activity of substances. In this paper, DPPH method has been applied to the bark extracts of the selected medicinal plants. UV-Vis spectrum of 1,1-diphenyl-2-picryl hydrazyl free radical $\left(\mathrm{DPPH}^{\circ}\right)$ shows a characteristic absorbance close to $515 \mathrm{~nm}$ in methanol. This method presents the advantage of using stable and commercially available free radical and has been 
extensively applied on plant extracts and on various food materials $[13,14]$.

In the field of pharmaceutical research, enzyme inhibition is an important area which has resulted in the discovery of a number of useful drugs. Specific inhibitors interact with enzymes and block their activity towards their corresponding physiological substrates. The importance of enzyme inhibitors as drugs is enormous, since these molecules have been used for treating a large number of physiological conditions. Plant derived protease inhibitors serve in the defense mechanisms of plants against pests and plant pathogens. These inhibitors can be classified into a number of families on the basis of their specificities to inhibit the cleavage of specific peptide sequences within the proteins.

Proteases refer to a group of enzymes, whose catalytic function is to hydrolyze peptide bond of protein. They play a key role in a variety of biological processes, both at the physiological level and in infection. Proteases are classified into serine, threonine, cysteine, aspartate, and glutamic acid proteases. Most widely studied group of proteases is serine proteases and many pathological disorders are caused by deficiencies in the normally exquisite regulation of the activity of proteolytic enzymes, resulting in abnormal tissue destruction and the aberrant processing of other proteins. Elastase, chymotrypsin, and trypsin are the subclass of serine proteases based on the type of substrate. Trypsin cleaves polypeptide chains on the C-terminal side of a positively charged side-chain containing arginine or lysine.

Acacia nilotica (Fabaceae) is used for cold, bronchitis, diarrhoea, dysentery, biliousness, bleeding piles, and leucoderma [15]. Acacia modesta commonly known as "Phulai" is chewed and sucked for gastric pain. Albizzia lebbeck (Mimosaceae) is used against cataract, asthma, ophthalmopathy, leprosy, diarrhea, and all types of poisoning [16]. Antiallergic [17], anti-inflammatory [18], and anticonvulsant [19] activities of this plant have also been documented. Cassia fistula (Fabaceae) has a high therapeutic value and is used to cure anorexia, rheumatism, inflammatory diseases, and skin disorders and as an analgesic. Besides, it also finds use in the treatment of haematemesis, pruritus, leucoderma, and diabetes. The hepatoprotective activity [20] and the hypoglycemic activity [21] have also been reported. Cinnamomum zeylanicum (Lauraceae) showed many biological properties as analgesic, antiseptic, antispasmodic, aphrodisiac, astringent, carminative, insecticide, and parasiticide. It has mildly astringent and aromatic properties and is used in European medicine. It has a place for the treatment of colic and diarrhea [22]. Different parts of Eucalyptus rostrata (Myrtaceae) are used in traditional medicine for the treatment of diarrhea, relaxed throats, chronic dysentery, malaria, infection of the upper respiratory tract, and certain skin diseases, and as an astringent in dentistry and for cuts [23]. According to Ayurveda and Unani system of medication, Eugenia jambolana (Myrtaceae) is sweet, digestive, astringent, used to cure bronchitis, asthma, dysentery, and ulcers. Its external use shows good wound healing properties [24].

Ficus (Moraceae) are being used traditionally in a wide variety of ethnomedical remedies all over the world [25].
Mangifera indica (Anacardiaceae) possesses various pharmacological activities, including anti-inflammatory, antimicrobial, antioxidant, hepatoprotective, and hypoglycemic activities. Mangiferin isolated from $M$. indica is effective in against herpes simplex virus type 2 in vitro. It also possesses immunomodulatory action [26]. Michelia champaca (Magnoliaceae) is used in the treatment of brain disorders fever, colic, leprosy, and postpartum protection, in childbirth, and as febrifuge. It is also used as anti-inflammatory and antipyretic agent [27]. Various parts of Mimusops elengi (Sapotaceae) have been used as a febrifuge, astringent, purgative, and stimulant [28]. The pounded seeds pasted with oil are used for the treatment of obstinate constipation [29]. Punica granatum (Punicaceae) is used to treat stomach ache and laxative and respiratory pathologies in traditional medicine [30]. Psidium guajava (Myrtaceae) is used as antidiarrhoeal, gastroenteritis, dysentery, antibacterial, colic, and pathogenic germs of the intestine [31]. Polyalthia longifolia (Annonaceae) is used as a febrifuge and depressed the heart, lowered blood pressure, and stimulated respiration [32]. The fungicidal effect of $P$. longifolia has also been reported by many workers [33]. Zizyphus jujuba (Rhamnaceae) possess multiple medicinal properties such as antifertility, analgesic, and antidiabetes [34].

The aim of this study was to screen the bark extracts with respect to their total phenolic contents, radical scavenging, and proteases activity in order to find new potential drugs from natural sources.

\section{Materials and Methods}

2.1. Chemicals and Reagents. Folin-Ciocalteu reagent (FC), 2,2-diphenyl-1-picrylhydrazyl (DPPH), and HPLC standards were purchased from Sigma-Aldrich (USA). Solvents and butylhydroxytoluene (BHT) of analytical grade were purchased from Panerac (Spain). N $\alpha$-benzoyl-DL-arginineparanitroanilide-HCL (BApNA), trypsin from bovine serum, and DMSO were purchased from Fluka (Germany). All other chemicals and reagents of analytical grade were from Merck (Germany).

2.2. Extraction of Phenolic Compounds. Plant materials were collected in January 2012, from Azad Kashmir region, Pakistan, and identified at the Department of Botany, University of Gujrat, Gujrat, while the bark of C. zeylanicum and A. cat$e c h u$ was purchased from local market. The bark was shadedried, pulverized, grinded to powder, and extracted (50 gm) with $100 \%$ methanol and acetone-water $(70: 30)$ separately at room temperature for seven days and at reflux temperature for five hours $(500 \mathrm{~mL}$ each). The crude extracts were filtered and concentrated at reduced pressure by using rotary evaporator.

2.3. Determination of Total Phenols. Total phenols in extracts were determined using Folin-Ciocalteu reagent [35]. $40 \mu \mathrm{L}$ of each sample $(2 \mathrm{mg} / \mathrm{mL})$ was mixed with $0.25 \mathrm{~mL}$ of FC reagent and $0.8 \mathrm{~mL}$ of $10 \%$ sodium carbonate solution. The mixture was allowed to stand for $30 \mathrm{~min}$ and the absorbance 
was measured at $765 \mathrm{~nm}$. The total phenolic contents were expressed as gallic acid equivalents (GAE) in $\mathrm{mg} / \mathrm{g}$ of crude extract. Correlation studies between total phenolic contents and $\%$ scavenging of DPPH were performed.

2.4. $D P P H^{*}$ Radical Scavenging Assay. The radical scavenging ability of extracts was measured using the method of Majinda et al. [36]. Methanolic solution $(1.0 \mathrm{~mL})$ of all the extracts $(2 \mathrm{mg} / \mathrm{mL})$ was added to $1.0 \mathrm{~mL}(0.2 \mathrm{mg} / \mathrm{mL})$ methanol solution of $\mathrm{DPPH}^{*}$ and absorbance was measured at $517 \mathrm{~nm}$ after thirty minutes.

The \% scavenging of $\mathrm{DPPH}^{*}$ was determined by the following formula:

$$
\begin{aligned}
& \text { \%Inhibition } \\
& \qquad=\frac{\text { Absorbance (blank) - Absorbance (test) }}{\text { Absorbance (blank) }} \times 100 .
\end{aligned}
$$

The amount of the sample was also determined by measuring decrease in absorbance at $517 \mathrm{~nm}$ to half of the initial value as $\mathrm{EC}_{50}$. Gallic acid and BHT were used as standard reference.

2.5. Protease Inhibition Assay. All the extracts were subjected to protease inhibition assay according to the method of Jedinák et al. [37], with some modification. Tris buffer $(100 \mathrm{mM})$ of $\mathrm{pH} 7.5$ was prepared by dissolving $12.1 \mathrm{~g}$ of Tris (hydroxymethyl)-aminomethane in distilled water and adjusted $\mathrm{pH} 7.5$ with $\mathrm{HCl}(5 \mathrm{M})$. The stock solution of trypsin was prepared by dissolving $2 \mathrm{mg}$ of trypsin in $10 \mathrm{~mL}$ of $1.0 \mathrm{mM}$ $\mathrm{HCl}$. N $\alpha$-benzoyl-DL-arginine-paranitroanilide hydrochloride (BApNA) was dissolved in DMSO $(20 \mathrm{mg} / \mathrm{mL})$. Enzyme $(0.3 \mathrm{~mL})$ and inhibitor $(100 \mu \mathrm{L})$ was incubated at $37^{\circ} \mathrm{C}$ for 15 minutes and then $0.6 \mathrm{mM}$ substrate was added and final volume was made $2.5 \mathrm{~mL}$ with Tris buffer. The reaction mixture was incubated at $37^{\circ} \mathrm{C}$ for 30 minutes. The reaction was quenched by adding $100 \mu \mathrm{L}$ of acetic acid (30\%) and read the absorbance at $410 \mathrm{~nm}$ using UV/Vis spectrophotometer. Phenylmethanesulfonylfluoride (PMSF) was used as positive inhibitor:

$$
\begin{aligned}
& \text { \%Inhibition } \\
& \qquad=\frac{\text { Absorbance (blank) }- \text { Absorbance (test) }}{\text { Absorbance (blank) }} \times 100 .
\end{aligned}
$$

2.6. High Performance Liquid Chromatography. Qualitative analysis of all plant extracts was carried out with high performance liquid chromatograph, HPLC-DAD system (Shimadzu, Kyoto, Japan) consisting of LC-20A pump, DGU20A degasser, SPD M-20A diode array detector, a manual sample injector with a $20 \mu \mathrm{L}$ sampling loop (Rheodyne, Cottati, CA, USA), and CTO-20 A column oven. Data was integrated by using HPLC 20A software. The measurements were performed at room temperature using reverse-phase Merck C-18 column $(4.6 \times 250 \mathrm{~mm}, 5 \mu \mathrm{m})$. The mobile phase was a mixture of methanol, water, and acetic acid $(50: 48: 2)$ with isocratic elution. The elution flow rate was $1.0 \mathrm{~mL} / \mathrm{min}$, duration of analysis was $20.0 \mathrm{~min}$, and UV detector was tuned to $254 \mathrm{~nm}$. For the sample preparation, $5.0 \mathrm{mg}$ of extract and for standard $0.05 \mathrm{mg}$ were dissolved separately in $5 \mathrm{~mL}$ of mobile phase.

2.7. Statistical Analysis. The data was analyzed using one-way analysis of variance (ANOVA) for repeated measurements. Duncan's multiple range tests were used to determine differences at each point which were considered significant at $P \leq 0.05$.

\section{Results and Discussion}

The bark powder of the selected medicinal plants was extracted in two different solvent systems, methanol (100\%) and acetone-water $(7: 3)$, by using cold maceration and at reflux temperature. Total phenolic contents of the extracts were measured by F.C method [35]. The results revealed that the methanolic extract of four species (A. nilotica, A. lebbeck, C. fistula, and $M$. indica) contained the highest amount of phenolic contents at reflux temperature. For the remaining extracts, methanol extraction at room temperature was found a useful method. No encouraging results were obtained in the acetone-water extracts. The methanolic extracts of the selected medicinal plants showed significant variation in the total phenolic contents ranging from 528 to $715 \mathrm{mg}$ of gallic acid equivalent (GAE/g of crude extract). The bark extract of $A$. nilotica contained the highest amount of phenolic compounds ( $715 \mathrm{mg}$ ), while the extract of $P$. granatum, M. elengi, and $M$. indica showed 712, 706, and $700 \mathrm{mg}$ of GAE/g of crude extract, respectively. $91.6 \%$ of the selected plant extracts contained more than $600 \mathrm{mg}$ of GAE/g, while $4.2 \%$ showed a range of 528-597 mg of GAE/g of crude extract (Table 1). $\mathrm{DPPH}^{\circ}$ assay was carried out using in vitro model to assess the ability of the bark extracts to scavenge the free radical. This method was found rapid and reliable which can be applied to a large number of plant extracts $[10,11]$. A total of 21 medicinal plant species from 11 families were collected, extracted, and tested. Their radical scavenging activity determined as \% scavenging of $\mathrm{DPPH}^{\circ}$, ranged from 87 to $96 \%$. Of the 21 extracts of the medicinal plants, 15 species showed \% scavenging activity from 90 to $96 \%$, while remaining in the range of 87 to $90 \%$. The highest activity (96\%) was exhibited by the extracts of $P$. granatum $\left(\mathrm{EC}_{50}=7 \mu \mathrm{g} / \mathrm{mL}\right)$ and $M$. indica $\left(\mathrm{EC}_{50}=\right.$ $14 \mu \mathrm{g} / \mathrm{mL}) .95 \%$ scavenging of $\mathrm{DPPH}^{\circ}$ was obtained for $A$. nilotica $\left(\mathrm{EC}_{50}=6 \mu \mathrm{g} / \mathrm{mL}\right)$, . racemosa $\left(\mathrm{EC}_{50}=11 \mu \mathrm{g} / \mathrm{mL}\right)$, and E. jambolana $\left(\mathrm{EC}_{50}=12 \mu \mathrm{g} / \mathrm{mL}\right)$. The extracts of $M$. elengi showed the lowest $\mathrm{EC}_{50}(3 \mu \mathrm{g} / \mathrm{mL})$ with $94 \%$ scavenging activity. Among the extracts which exhibited $92 \%$ radical scavenging activity, $A$. modesta was the most effective with $\mathrm{EC}_{50}=8 \mu \mathrm{g} / \mathrm{mL}$, while the extracts with $91 \%$ scavenging activity (M. champaca and P. guajava; $\mathrm{EC}_{50}=13 \mu \mathrm{g} / \mathrm{mL}, 15 \mu \mathrm{g} / \mathrm{mL}$, resp.) and with $90 \%$ (A. catechu, . religiosa; $\mathrm{EC}_{50}=8 \mu \mathrm{g} / \mathrm{mL}$, $9 \mu \mathrm{g} / \mathrm{mL}$, resp.) showed close results with respect to minimum concentration required to inhibit $50 \%$ of the initial concentration of $\mathrm{DPPH}^{\circ}$. A large variation in the $\mathrm{EC}_{50}$ values of C. fistula $(4 \mu \mathrm{g} / \mathrm{mL})$ was observed with $88 \%$ scavenging activity as compared to two other species (E. Suberosa, $\mathrm{EC}_{50}=$ $28 \mu \mathrm{g} / \mathrm{mL}$, and F. Infectoria, $\mathrm{EC}_{50}=24 \mu \mathrm{g} / \mathrm{mL}$ ) with same $\%$ 
TABLE 1: Total phenols, \% scavenging of DPPH, \% inhibition of trypsin, and $\mathrm{IC}_{50}$ value of medicinal plants.

\begin{tabular}{|c|c|c|c|c|c|}
\hline Plant name & $\begin{array}{c}\text { TP } \\
\text { (mg GAE/g crude extract) }\end{array}$ & $\begin{array}{c}\text { DPPH } \\
\text { scavenging (\%) }\end{array}$ & $\mathrm{IC}_{50}(\mu \mathrm{g} / \mathrm{mL})$ & $\begin{array}{c}\text { Trypsin } \\
\text { inhibition (\%) }\end{array}$ & Reported phenols \\
\hline A. catechu & $608 \pm 20$ & $90 \pm 1$ & $8 \pm 1$ & $43 \pm 2$ & Flavonol derivative \\
\hline A. lebbeck & $625 \pm 26$ & $92 \pm 1$ & $19 \pm 2$ & $25 \pm 1$ & - \\
\hline A. modesta & $661 \pm 15$ & $92 \pm 2$ & $8 \pm 1$ & $37 \pm 2$ & - \\
\hline A. nilotica & $715 \pm 17$ & $95 \pm 2$ & $6 \pm 1$ & $52 \pm 3$ & $\begin{array}{l}\text { Epicatechin, flavonol, and } \\
\text { catechin derivatives }\end{array}$ \\
\hline C. fistula & $597 \pm 13$ & $88 \pm 1$ & $4 \pm 1$ & $56 \pm 3$ & $\begin{array}{c}\text { Catechin, flavonol } \\
\text { derivative }\end{array}$ \\
\hline C. zeylanicum & $627 \pm 10$ & $92 \pm 1$ & $13 \pm 3$ & $32 \pm 2$ & Epicatechin derivative \\
\hline E. jambolana & $692 \pm 24$ & $95 \pm 2$ & $12 \pm 2$ & $46 \pm 2$ & $\begin{array}{c}\text { Ellagic acid, kaempherol } \\
\text { derivative }\end{array}$ \\
\hline E. suberosa & $564 \pm 16$ & $88 \pm 1$ & $28 \pm 4$ & $27 \pm 1$ & - \\
\hline F. benghalensis & $618 \pm 24$ & $89 \pm 1$ & $16 \pm 2$ & $21 \pm 1$ & $\begin{array}{c}\text { Leucopelargon derivative, } \\
\text { leucocyanidin }\end{array}$ \\
\hline F. infectoria & $576 \pm 21$ & $88 \pm 1$ & $24 \pm 3$ & $28 \pm 1$ & - \\
\hline F. racemosa & $692 \pm 27$ & $95 \pm 2$ & $11 \pm 2$ & $25 \pm 2$ & Racemosic acid, bergenin \\
\hline F. religiosa & $635 \pm 15$ & $90 \pm 1$ & $9 \pm 2$ & $32 \pm 1$ & - \\
\hline P. guajava & $656 \pm 10$ & $91 \pm 1$ & $15 \pm 2$ & $30 \pm 1$ & Catechin derivative \\
\hline P. granatum & $712 \pm 9$ & $96 \pm 1$ & $7 \pm 1$ & $27 \pm 2$ & $\begin{array}{l}\text { Ellagic acid, isoflavone, and } \\
\text { gallic acid derivative }\end{array}$ \\
\hline P. longifolia & $528 \pm 16$ & $87 \pm 1$ & $65 \pm 5$ & $22 \pm 2$ & - \\
\hline P. roxburghii & $570 \pm 22$ & $87 \pm 1$ & $11 \pm 2$ & $39 \pm 2$ & Ferulic acid derivative \\
\hline M. champaca & $650 \pm 25$ & $91 \pm 1$ & $13 \pm 3$ & $33 \pm 3$ & - \\
\hline M. elengi & $706 \pm 9$ & $94 \pm 1$ & $3 \pm 0$ & $29 \pm 2$ & Myricetin-3-rhamnoside \\
\hline M. indica & $700 \pm 13$ & $96 \pm 2$ & $12 \pm 1$ & $36 \pm 1$ & $\begin{array}{l}\text { 1,7-dihydroxy xanthone, } \\
\text { gallic acid and chromone } \\
\text { derivative }\end{array}$ \\
\hline Z. jujuba & $670 \pm 17$ & $94 \pm 1$ & $17 \pm 2$ & $44 \pm 2$ & $\begin{array}{l}\text { Flavonol, quercetin and } \\
\text { catechin derivative }\end{array}$ \\
\hline
\end{tabular}

Results are mean \pm SD $(n=3)$; - : not found.

radical scavenging activity. The extract of $P$. roxburghii with $87 \%$ scavenging of $\mathrm{DPPH}^{*}$ showed $\mathrm{EC}_{50}=11 \mu \mathrm{g} / \mathrm{mL}$, while $P$. longifolia exhibited the highest $\mathrm{EC}_{50}$ values $=65 \mu \mathrm{g} / \mathrm{mL}$ of the selected plants with same \% scavenging activity (Figure 1).

The correlation coefficients $\left(R^{2}\right)$ of antioxidant activity with total phenolic contents of methanolic extract were found 0.8874 (room temperature) and 0.8327 (reflux temperature) and acetone-water 0.8433 (room temperature) and 0.7580 (reflux temperature).

The phenolic compounds in the methanolic extracts of $E$. jambolana, A. nilotica, and C. zeylanicum were identified and confirmed by high performance liquid chromatography with standard samples. The results of these plant extracts along standards are shown in Figures 2-5. Gallic acid was identified in the extract of $C$. zeylanicum and A. nilotica appearing at $\mathrm{RT}=2.93 \mathrm{~min}$; tannic acid at $\mathrm{RT}=2.77 \mathrm{~min}$ (E. suberosa, $A$. catechu, P. longifolia, E. jambolana, Z. jujuba, F. infectoria, and A. nilotica); quercetin at RT $=13.7 \mathrm{~min}($ C. zeylanicum $)$; rutin

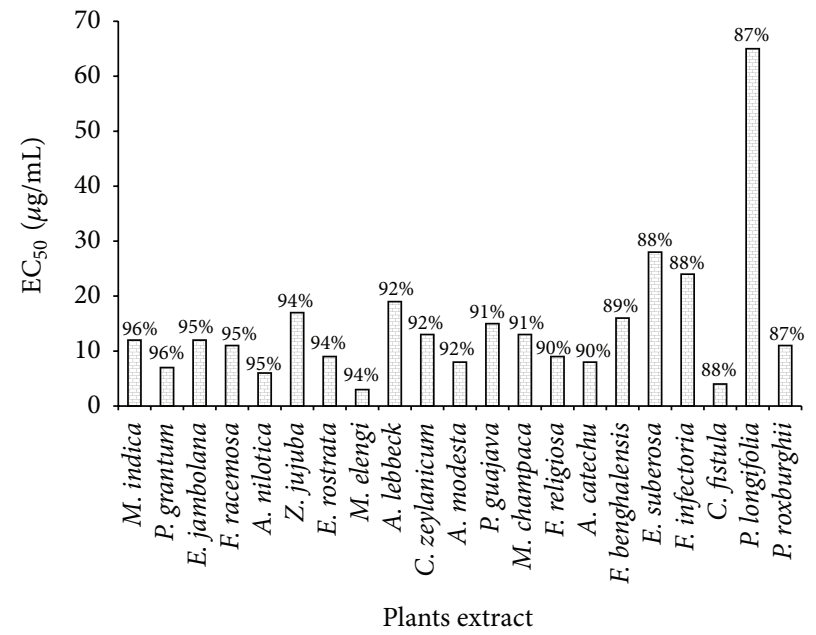

FIGURE 1: $\mathrm{EC}_{50}$ values of the selected medicinal plant extracts. 


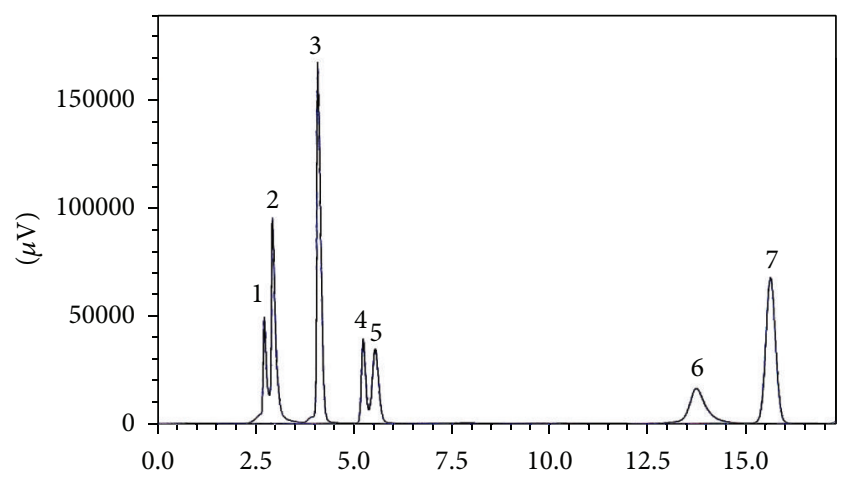

FIGURE 2: HPLC analysis of standards; $1=$ tannic acid, $2=$ gallic acid, $3=$ catechin, $4=$ hesperidin, $5=$ rutin, $6=$ quercetin, and $7=$ cinnamic acid.

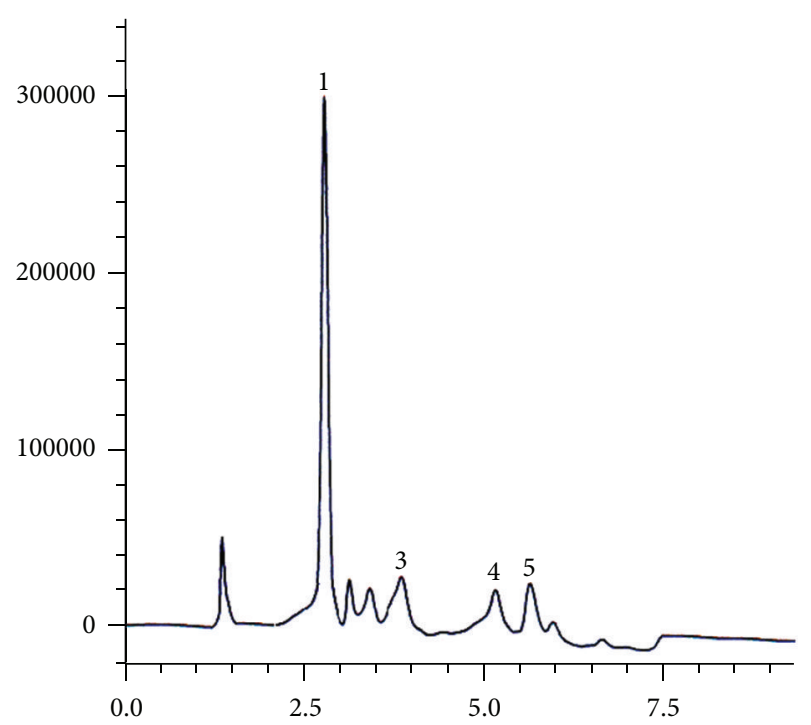

FIGURE 3: HPLC analysis of methanolic extract of E. jambolana $(1=$ tannic acid, $3=$ catechin, $4=$ hesperidin, and $5=$ rutin).

at $\mathrm{RT}=5.6 \mathrm{~min}$ (P. longifolia and E. jambolana); catechin at $\mathrm{RT}=4.2 \mathrm{~min}$ ( $Z$. jujuba, E. jambolana, and A. nilotica); hesperidin at $\mathrm{RT}=5.3 \mathrm{~min}$ (A. nilotica, E. jambolana, and $C$. zeylanicum); cinnamic acid at $\mathrm{RT}=15.6 \mathrm{~min}$ (C. zeylanicum).

Plant polyphenols probably constitute the largest group of plant-secondary metabolites, which have an important application as defense antioxidants. They include phenols, phenolic acids, flavonoids, tannins, and lignans. They possess an aromatic ring bearing one or more hydroxyl constituents including their functional derivatives [38, 39]. Antioxidant activity of phenolic compounds is correlated to their chemical structure. Flavonoids have the basic skeleton of diphenyl propane with different oxidations of central pyran ring. In plants, flavonoids are found as O-glycosides with sugar or through $\mathrm{C}$-glycoside, but some are present as aglycones. In general O-glycosides at C-3 of ring "C" have lower radical scavenging power than those having a free $-\mathrm{OH}$ at $\mathrm{C}-3$ because it is thought to be related to the reduction of the free radical [40].

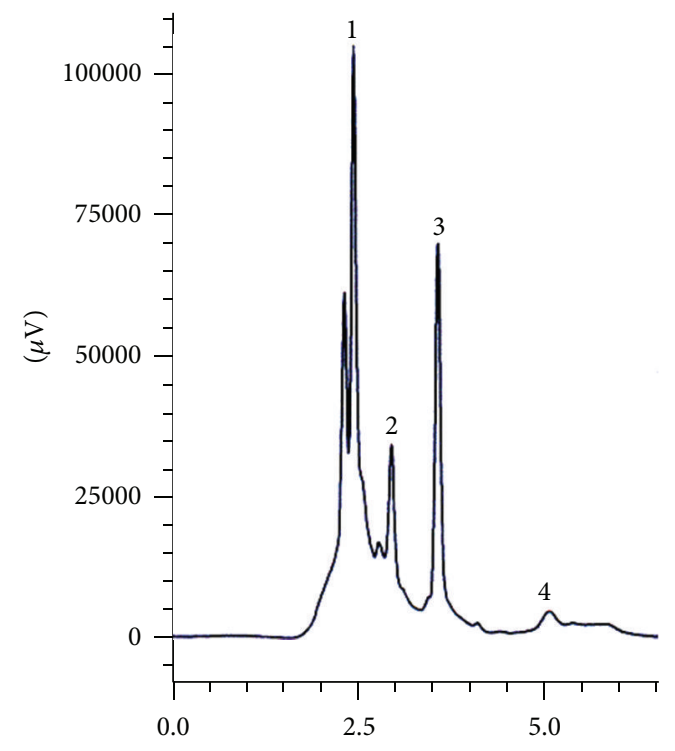

FIgURE 4: HPLC analysis of methanolic extract of $A$. nilotica $(1=$ tannic acid, 2 = gallic acid, $3=$ catechin, and $4=$ hesperidin).

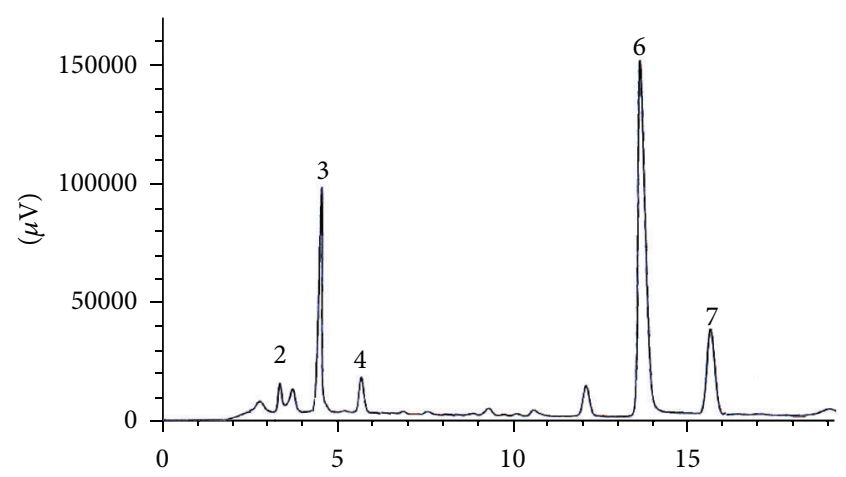

Figure 5: HPLC analysis of methanolic extract of C. zeylanicum $(2=$ gallic acid, $3=$ catechin, $4=$ hesperidin, $6=$ quercetin, and $7=$ cinnamic acid).

Bark of the selected medicinal plants is associated with the cure of many ailments (Table 2). Quantitative data on the phenolic compounds in the bark extracts of the selected plants was not found in the literature but the main constituents are suggested to be phenolic acids such as gallic acid, ellagic acid, rosmerinic acid, tannic acid, fistulic acid, cinnamic acid, and ferulic acid in P. granatum, $M$. indica, $F$. racemosa, E. jambolana, C. fistula, and P. roxburghii [41-43] (Table 2). Myricetin glycoside, 4-O-acetyl myricetin, eujambin, and eujambolin have been identified in E. jambolana $[44,45]$. Myricitine was isolated from M. elengi and cinnamic acid derivative from $Z$. jujuba [46]. Epicatechin glycosides were reported from C. fistula [47], epicatechin derivatives, Psidinin A, B, and C, from P. guajava, xanthone and xanthene derivative from $M$. indica [48], and quercetin and kaemferol derivative from E. rostrata. Ellagic acid glycosides were identified in the bark extract of $P$. grantum [49]; gallic acid, protocatechuic acid, pyrocatechol, (+)-catechin, (-) 
TABLE 2: Medicinal uses of stem bark of the selected medicinal plants.

\begin{tabular}{|c|c|c|c|}
\hline Family & Plant name & Uses & References \\
\hline \multirow{6}{*}{ Fabaceae } & Acacia nilotica $\mathrm{L}$. & Gargle, diarrhea, antibacterial, antidiabetic, and antioxidant & {$[51-54]$} \\
\hline & Acacia modesta Wall & - & - \\
\hline & Acacia catechu L. & $\begin{array}{l}\text { Melancholia, conjunctivitis, haemoptysis, skin diseases, asthma sore } \\
\text { mouth, chest pain, antioxidant, colicky pain, gravel, bronchitis, and } \\
\text { liver diseases }\end{array}$ & {$[54,55]$} \\
\hline & Albizia lebbeck L. & $\begin{array}{l}\text { Anti-inflammatory, antioxidant, leprosy, brinchis, paralysis, and } \\
\text { helminthiasis }\end{array}$ & {$[54,56]$} \\
\hline & Cassia fistula $\mathrm{L}$ & $\begin{array}{l}\text { Astringent, purgative, anthelmintic, diuretic, laxative, expectorant, } \\
\text { anti-inflammatory, cathartic, and antioxidant }\end{array}$ & {$[57]$} \\
\hline & Erythrina suberosa Roxb & - & - \\
\hline \multirow{4}{*}{ Moraceae } & Ficus bengalensis $\mathrm{L}$. & $\begin{array}{l}\text { Hypercholesterolemia, hyperlipidaemia, antidiabetic, antidiarrhoeal, } \\
\text { dysentery, diabetes and skin diseases, antioxidant and piles }\end{array}$ & {$[54,58]$} \\
\hline & Ficus religiosa $\mathrm{L}$. & $\begin{array}{l}\text { Inflammations, antimicrobial, swelling of neck, gonorrhea, scabies, } \\
\text { strengthening gums, antimicrobial, astringent, sweet, cooling, } \\
\text { aphrodisiac, antiseptic antioxidant, expectorant, and antiphlogistic }\end{array}$ & {$[54,58]$} \\
\hline & Ficus racemosa Roxb & Antioxidant, antimicrobial, wound healingdiabetic, and anthelmintic & {$[54,58]$} \\
\hline & Ficus infectoria Roxb & - & - \\
\hline \multirow{3}{*}{ Myrtaceae } & Eugenia jambolana L. & $\begin{array}{l}\text { Acrid, sweet, digestive, astringent, anthelmintic, sore throat, } \\
\text { bronchitis, asthma, thirst, biliousness, dysentery, ulcers, and } \\
\text { antioxidant }\end{array}$ & {$[45]$} \\
\hline & Psidium guajava L. & $\begin{array}{l}\text { Astringent, febrifuge, antiseptic, antimicrobial, diarrhoea, stomach } \\
\text { ache and diabetes, and antioxidant }\end{array}$ & {$[59]$} \\
\hline & $\begin{array}{l}\text { Eucalyptus rostrata } \\
\text { Schlecht }\end{array}$ & $\begin{array}{l}\text { Antimicrobial and gastroprotective dysentery, microbial infections, } \\
\text { diarrhoea, helminthiasis, haemorrhage, respiratory pathologies, } \\
\text { respiratory disease, astringent, anthelmintic, aphrodisiacs, laxative, } \\
\text { diuretic, stomachic, cardio tonic, and antioxidant }\end{array}$ & {$[57,58,60]$} \\
\hline Lauraceae & $\begin{array}{l}\text { Cinnamomum zeylanicum } \\
\text { Blume }\end{array}$ & $\begin{array}{l}\text { Flavoring agent, cardiac stimulant, tonic for stomach, intestine, } \\
\text { antispasmodic, antidysenteric, aphrodisiacs semenogogues, and } \\
\text { antioxidant }\end{array}$ & {$[61]$} \\
\hline Magnoliaceae & Michelia champaca L. & $\begin{array}{l}\text { Hypoglycemic, stimulant, diuretic, febrifuge, purgative, } \\
\text { immounogogue, and stimulant }\end{array}$ & {$[58]$} \\
\hline Pinaceae & Pinus roxburghii Sarg & - & - \\
\hline Rhamnaceae & Zizyphus jujube L. & $\begin{array}{l}\text { Antifertility, analgesic, antidiabetes, intestinal spasms, venereal } \\
\text { diseases, and antioxidant }\end{array}$ & {$[58]$} \\
\hline Anacardiaceae & Mangifera indica L. & $\begin{array}{l}\text { Antihelminthic, antiallergic, acrid, refrigerant, styptic, antisyphilitic } \\
\text { and anti-inflammatory and antioxidant }\end{array}$ & {$[58,59]$} \\
\hline Sapotaceae & Mimusops elengi L. & $\begin{array}{l}\text { Acrid, astringent, cooling, anthelmintic, gargle, odontopathy, } \\
\text { ulemorrhagia, diarrhea, and dysentery }\end{array}$ & {$[58]$} \\
\hline Annonaceae & Polyalthia longifolia Sonn & Febrifuge, skin diseases, diabetes, hypertension, and bleeding piles & {$[58]$} \\
\hline
\end{tabular}

-: no reported activity.

epigallocatechin-7-gallate, and (-) epigallocatechin-5, 7digallate were identified in the extract of A. nilotica [24].

Statistical results of the correlation studies (average $R^{2}=$ 0.8874 ) between antiradical scavenging activity and total phenolic contents strongly suggested that the phenolic compounds were the dominant antioxidant in the methanolic extract of the bark of selected plants (Table 2). Our results are in agreement with the reported data $[6,50]$. The analysis of phenolic compounds and their correlation with radical scavenging activity in "E. rostrata, $M$. champaca, A. modesta, $P$. roxburghii, $P$. longifolia, E. suberosa, $M$. elengi, and F. infectoria" have been reported for the first time. Figures 3-5 display the selected HPLC profile of the medicinal plants. However, main phenolic compounds in 13 medicinal plants 
TABLE 3: Compounds identified by HPLC in selected medicinal plants.

\begin{tabular}{|c|c|}
\hline Name of plant & Compounds identified with HPLC \\
\hline \multirow{4}{*}{ C. zeylanicum } & Gallic acid \\
\hline & Cinnamic acid \\
\hline & Hesperidin \\
\hline & Quercetin \\
\hline \multirow{4}{*}{ E. jambolana } & Tannic acid \\
\hline & Rutin \\
\hline & Hesperidin \\
\hline & Catechin \\
\hline A. catechu & Tannic acid \\
\hline F. infectoria & Tannic acid \\
\hline \multirow{3}{*}{ A. nilotica } & Gallic acid \\
\hline & Catechin \\
\hline & Tannic acid \\
\hline \multirow{2}{*}{ Z. jujuba } & Catechin \\
\hline & Tannic acid \\
\hline \multirow{2}{*}{ P. longifolia } & Rutin \\
\hline & Tannic acid \\
\hline E. suberosa & Tannic acid \\
\hline
\end{tabular}

could not be identified in this study (Table 3 ). Therefore, further chemical identification will be required to reveal the possible structure activity relationship.

\section{Conflict of Interests}

The authors declare that there is no conflict of interests regarding the publication of this paper.

\section{References}

[1] E. B. Rimm, A. Ascherio, E. Giovannucci, D. Spiegelman, M. J. Stampfer, and W. C. Willett, "Vegetable, fruit, and cereal fiber intake and risk of coronary heart disease among men," The Journal of the American Medical Association, vol. 275, no. 6, pp. 447-451, 1996.

[2] K. A. Steinmetz and J. D. Potter, "Vegetables, fruit, and cancer prevention: a review," Journal of the American Dietetic Association, vol. 96, no. 10, pp. 1027-1039, 1996.

[3] N. Ito, M. Hirose, S. Fukushima, H. Tsuda, T. Shirai, and M. Tatematsu, "Studies on antioxidants: their carcinogenic and modifying effects on chemical carcinogenesis," Food and Chemical Toxicology, vol. 24, no. 10-11, pp. 1071-1081, 1986.

[4] P. T. Gardner, T. A. C. White, D. B. McPhail, and G. G. Duthie, "The relative contributions of vitamin $\mathrm{C}$, carotenoids and phenolics to the antioxidant potential of fruit juices," Food Chemistry, vol. 68, no. 4, pp. 471-474, 2000.

[5] K. A. Youdim, J. P. E. Spencer, H. Schroeter, and C. Rice-Evans, "Dietary flavonoids as potential neuroprotectants," Biological Chemistry, vol. 383, no. 3-4, pp. 503-519, 2002.

[6] W. Zheng and S. Y. Wang, "Antioxidant activity and phenolic compounds in selected herbs," Journal of Agricultural and Food Chemistry, vol. 49, no. 11, pp. 5165-5170, 2001.

[7] M. A. Anagnostopoulou, P. Kefalas, V. P. Papageorgiou, A. N. Assimopoulou, and D. Boskou, "Radical scavenging activity of various extracts and fractions of sweet orange peel (Citrus sinensis)," Food Chemistry, vol. 94, no. 1, pp. 19-25, 2006.

[8] H. W. Heldt, Plant Biochemistry and Molecular Biology, Oxford University Press, Oxford, UK, 1997.

[9] C. A. Rice-Evans, N. J. Miller, P. G. Bolwell, P. M. Bramley, and J. B. Pridham, "The relative antioxidant activities of plant-derived polyphenolic flavonoids," Free Radical Research, vol. 22, no. 4, pp. 375-383, 1995.

[10] N. J. Miller, C. Rice-Evans, M. J. Davies, V. Gopinathan, and A. Milner, "A novel method for measuring antioxidant capacity and its application to monitoring the antioxidant status in premature neonates," Clinical Science, vol. 84, no. 4, pp. 407-412, 1993.

[11] W. Brand-Williams, M. E. Cuvelier, and C. Berset, "Use of a free radical method to evaluate antioxidant activity," LWT-Food Science and Technology, vol. 28, no. 1, pp. 25-30, 1995.

[12] V. Fogliano, V. Verde, G. Randazzo, and A. Ritieni, "Method for measuring antioxidant activity and its application to monitoring the antioxidant capacity of wines," Journal of Agricultural and Food Chemistry, vol. 47, no. 3, pp. 1035-1040, 1999.

[13] D. C. Porto, S. Calligaris, E. Celotti, and M. C. Nicoli, "Antiradical properties of commercial cognacs assessed by the DPPH(.) test," Journal of Agricultural and Food Chemistry, vol. 48, no. 9, pp. 4241-4245, 2000.

[14] C. Sánchez-Moreno, L. Plaza, B. De Ancos, and M. P. Cano, "Quantitative bioactive compounds assessment and their relative contribution to the antioxidant capacity of commercial orange juices," Journal of the Science of Food and Agriculture, vol. 83, no. 5, pp. 430-439, 2003.

[15] S. P. Ambasta, The Useful Plants of India, Publication and Information Directorate, CSIR, New Delhi, India, 1994.

[16] K. Rajagopalan, V. V. Sivarajan, and P. R. Varier, Indian Medicinal Plants, vol. 1, Orient Longmans, Madras, India, 1993.

[17] R. M. Tripathi, P. C. Sen, and P. K. Das, "Studies on the mechanism of action of Albizzia lebbeck, an Indian indigenous drug used in the treatment of atopic allergy," Journal of Ethnopharmacology, vol. 1, no. 4, pp. 385-396, 1979.

[18] K. D. Anish, A. Firoj, S. C. Bachar, J. Kundu, and D. Shrabanti, "Antiinflammatory effect of Albizzia lebbeck (Benth) Bark," OnLine Journal of Biological Sciences, vol. 3, pp. 685-687, 2003.

[19] V. S. Kasture, S. B. Kasture, and S. C. Pal, "Anticonvulsant activity of Albizzia lebbeck leaves," Indian Journal of Experimental Biology, vol. 34, no. 1, pp. 78-80, 1996.

[20] T. Bhakta, S. Banerjee, S. C. Mandal, T. K. Maity, B. P. Saha, and M. Pal, "Hepatoprotective activity of Cassia fistula leaf extract," Phytomedicine, vol. 8, no. 3, pp. 220-224, 2001.

[21] M. Espósito Avella, A. Díaz, I. de Gracia, R. de Tello, and M. P. Gupta, "Evaluation of traditional medicine: effects of Cajanus cajan L. and of Cassia fistula L. on carbohydrate metabolism in mice," Revista medica de Panama, vol. 16, no. 1, pp. 39-45, 1991.

[22] I. H. Burkill, A Dictionary of the Economic Products of the Malay Peninsular, Ministry of Agriculture and Cooperatives, Kuala Lumpur, Malaysia, 2nd edition, 1966.

[23] B. N. Sastri, The Wealth of India, Council of Scientific and Industrial Research, New Delhi, India, 1952.

[24] K. R. Kartikar and B. D. Basu, Indian Medicinal Plants, vol. 2, Periodical Experts, New Delhi, India, 1975.

[25] A. Hansson, J. C. Zelada, and H. P. Noriega, "Reevaluation of risks with the use of Ficus insipida latex as a traditional anthelmintic remedy in the Amazon," Journal of Ethnopharmacology, vol. 98, no. 3, pp. 251-257, 2005.

[26] X.-M. Zhu, J.-X. Song, Z.-Z. Huang, Y.-M. Wu, and M.-J. Yu, "Antiviral activity of mangiferin against herpes simplex virus 
type 2 in vitro," Acta Pharmacologica Sinica, vol. 14, no. 5, pp. 452-454, 1993.

[27] T. Clayton, P. Saralamp, W. Chuakul, and R. Temsiririkkul, Medicinal Plants in Siri Ruckhachati Garden, Faculty of Pharmacy, Mahidol University, 1994.

[28] K. M. Nadkarni, Indian Materia Medica, vol. 1, Popular Praashan Pvt. Ltd, Mumbai, India, 1976.

[29] N. Jahan, W. Ahmed, and A. Malik, "New steroidal glycosides from Mimusops elengi," Journal of Natural Products, vol. 58, no. 8, pp. 1244-1247, 1995.

[30] M. O. Fatope, S. K. S. Al Burtomani, and Y. Takeda, "Monoacylglycerol from Punica granatum seed oil," Journal of Agricultural and Food Chemistry, vol. 50, no. 2, pp. 357-360, 2002.

[31] A. Aguilar, A. Argueta, and L. Cano, Flora Medicinal Indígena de México, vol. 2, Instituto Nacional Indigenista, México, Mexico, 1994.

[32] S. Faizi, N. R. Mughal, R. A. Khan et al., "Evaluation of antimicrobial property of Polyalthia longifolia var. pendula: isolation of a lactone as the active antibacterial agent from the ethanol extract of stem," Phytotherapy Research, vol. 17, no. 10, pp. 1177-1181, 2003.

[33] R. Nair and S. Chanda, "Evaluation of Polyalthia longifolia (Sonn.) Thw. leaf extract for antifungal activity," Journal of Cell \& Tissue Research, vol. 1, pp. 581-584, 2006.

[34] A. Erenmemisoglu, F. Kelestimur, A. N. Koker, H. Ustun, Y. Tekol, and M. Ustdal, "Hypoglycaemic effect of Zizyphus jujuba leaves," Journal of Pharmacy and Pharmacology, vol. 47, no. 1, pp. 72-74, 1995.

[35] V. L. Singleton and J. A. Rossi, "olorimetry of total phenolics with phosphomolybdic-phosphotungstic acid reagents," American Journal of Enology and Viticulture, vol. 16, pp. 144-158, 1995.

[36] R. R. T. Majinda, P. Erasto, and G. Bojase-Moleta, "Antimicrobial and antioxidant flavonoids from the root wood of Bolusanthus speciosus," Phytochemistry, vol. 65, no. 7, pp. 875880, 2004.

[37] A. Jedinák, T. Maliar, D. Grančai, and M. Nagy, "Inhibition activities of natural products on serine proteases," Phytotherapy Research, vol. 20, no. 3, pp. 214-217, 2006.

[38] F. Shahidi and M. Naczk, Food Phenolics: Sources, Chemistry, Effects and Applications, Technomic Publishing, Lancaster, Pa, USA, 1995.

[39] D. Strack, "Phenolic metabolism," in Plant Biochemistry, P. M. Dey and J. B. Harborne, Eds., Academic Press, London, UK, 1997.

[40] S. Burda and W. Oleszek, "Antioxidant and antiradical activities of flavonoids," Journal of Agricultural and Food Chemistry, vol. 49, no. 6, pp. 2774-2779, 2001.

[41] D. M. Smith and J. B. Harborne, "Xanthones in the appalachian Asplenium complex," Phytochemistry, vol.10, no. 9, pp. 2117-2119, 1971.

[42] B. Theeshan, S. N. Vidushi, and I. A. Okezie, "Phytochemical constituents of Cassia fistula," African Journal of Biotechnology, vol. 4, no. 13, pp. 1530-1540, 2005.

[43] S. A. A. El-Toumy and H. W. Rauwald, "Two ellagitannins from Punica granatum heartwood," Phytochemistry, vol. 61, no. 8, pp. 971-974, 2002.

[44] N. A. M. Saleh, H. Fritsch, P. Witkop, and H. Grisebach, "UDPGlucose: cyanidin 3-O-glucosyltransferase from cell cultures of Haplopappus gracilis," Planta, vol. 133, no. 1, pp. 41-45, 1976.

[45] H. Sagrawat, A. S. Mann, and M. D. Kharya, "Pharmacological potential of Eugenia jambolana: a review," Pharmacognosy Magazine, vol. 2, pp. 96-105, 2006.
[46] N. Okamura, A. Yagi, and I. Nishioka, "Studies on the constituents of Zizyphi Fructus. V. structures of glycosides of benzyl alcohol, vomifoliol and naringenin," Chemical and Pharmaceutical Bulletin, vol. 29, no. 12, pp. 3507-3514, 1981.

[47] S. Morimoto, G. Nonaka, and I. Nishioka, "Tannins and related compounds. LX: isolation and characterization of proanthocyanidins with a doubly-linked Unit from Vaccinium vitis-idaea L," Chemical and Pharmaceutical Bulletin, vol. 36, pp. 33-38, 1988.

[48] T. Tanaka, N. Ishida, M. Ishimatsu, G. Nonaka, and I. Nishioka, "Tannins and related compounds. CXVI. Six new complex tannins, guajavins, psidinins and psiguavin from the bark of Psidium guajava L.," Chemical and Pharmaceutical Bulletin, vol. 40, no. 8, pp. 2092-2098, 1992.

[49] S. A. A. El-Toumy and H. W. Rauwald, "Two ellagitannins from Punica granatum heartwood," Phytochemistry, vol. 61, no. 8, pp. 971-974, 2002.

[50] Y. Cai, Q. Luo, M. Sun, and H. Corke, "Antioxidant activity and phenolic compounds of 112 traditional Chinese medicinal plants associated with anticancer," Life Sciences, vol. 74, no. 17, pp. 2157-2184, 2004.

[51] B. Mahesh and S. Satish, "Antimicrobial activity of some important medicinal plant against plant and human pathogens," World Journal of Agricultural Sciences, vol. 4, pp. 839-843, 2008.

[52] A. Jabeen, M. A. Khan, M. Ahmad, M. Zafar, and F. Ahmad, "Indigenous uses of economically important flora of Margallah Hills National Park, Islamabad, Pakistan," African Journal of Biotechnology, vol. 8, no. 5, pp. 763-784, 2009.

[53] A. Banso, "Phytochemical and antibacterial investigation of bark extracts of Acacia nilotica," Journal of Medicinal Plants Research, vol. 3, no. 2, pp. 82-85, 2009.

[54] V. K. Alluri, R. V. N. Tayi, S. Dodda, V. Mulabagal, T. HsinSheng, and V. S. Gottumukkala, "Biological screening of medicinal plants collected from Eastern Ghats of India using Artemia salina," International Journal of Applied Science and Engineering Research, vol. 4, pp. 115-125, 2006.

[55] T. G. Nagaraja, S. V. Sarang, and D. C. Jambhale, "Evaluation of antimycotic activity of Acacia catechu Willd," Journal of Biopesticides, vol. 1, pp. 197-198, 2008.

[56] K. Arvind, A. K. Saluja, U. D. Shah, and A. V. Mayavanshi, "Pharmacological potential of Albizzia lebbeck: a review," Pharmacognosy Magazine, vol. 1, pp. 171-174, 2007.

[57] V. Duraipandiyan, M. Ayyanar, and S. Ignacimuthu, "Antimicrobial activity of some ethnomedicinal plants used by Paliyar tribe from Tamil Nadu, India," BMC Complementary and Alternative Medicine, vol. 6, article no. 35, 2006.

[58] A. B. D. Selvam, "Inventory of vegetable crude drug samples housed in botanical survey of India, Howrah," Pharmacognosy Magazine, vol. 2, no. 3, pp. 61-94, 2008.

[59] D. A. Akinpelu and T. M. Onakoya, "Antimicrobial activities of medicinal plants used in folklore remedies in south-western," African Journal of Biotechnology, vol. 5, no. 11, pp. 1078-1081, 2006.

[60] B. A. Adeniyi, T. O. Lawal, and S. B. Olaleye, "Antimicrobial and gastroprotective activities of Eucalyptus camaldulensis (Myrtaceae) crude extracts," Journal of Biological Sciences, vol. 6, no. 6, pp. 1141-1145, 2006.

[61] A. H. Shah, A. H. Al-Shareef, A. M. Ageel, and S. Qureshi, "Toxicity studies in mice of common spices, Cinnamomum zeylanicum bark and Piper longum fruits," Plant Foods for Human Nutrition, vol. 52, no. 3, pp. 231-239, 1998. 

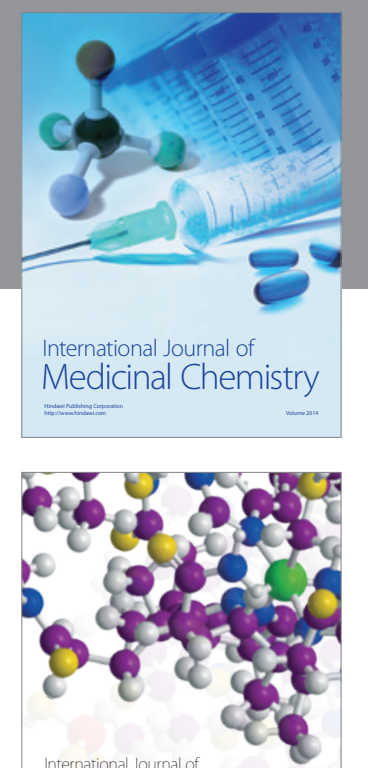

\section{Carbohydrate} Chemistry

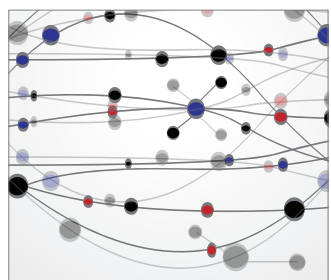

The Scientific World Journal
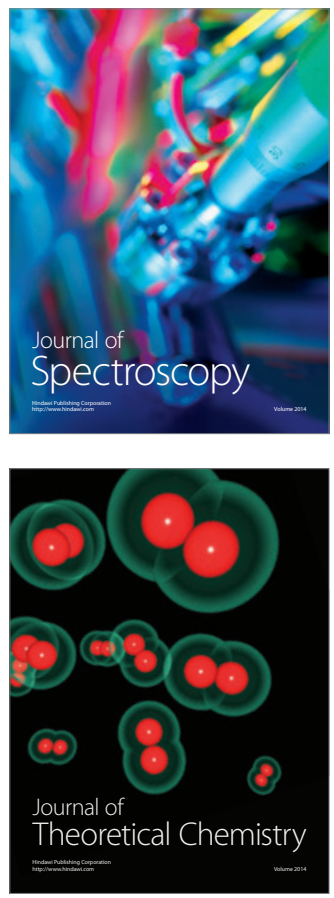
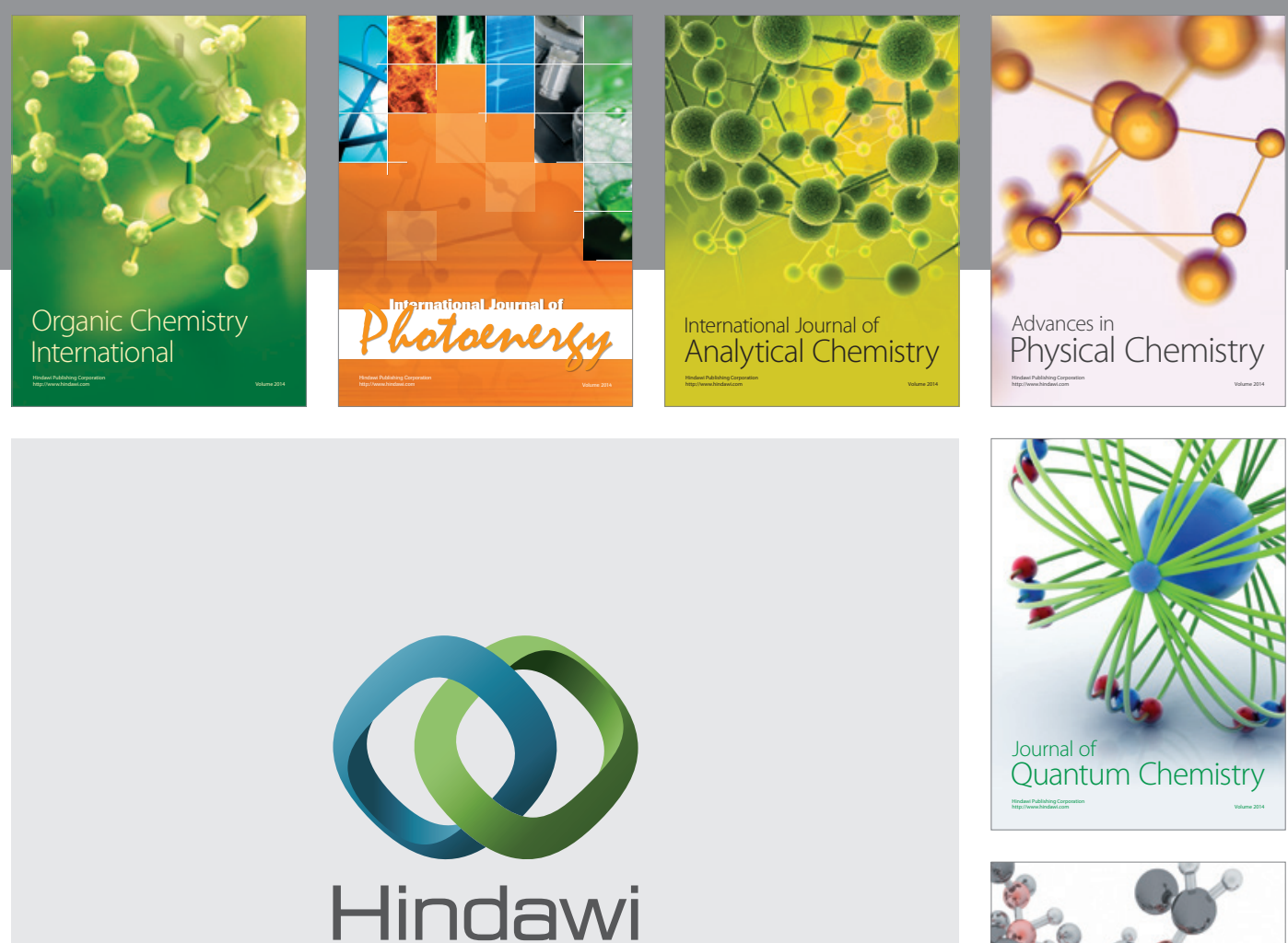

Submit your manuscripts at

http://www.hindawi.com

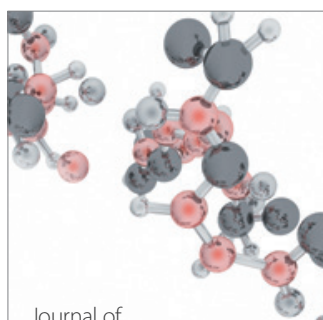

Analytical Methods

in Chemistry

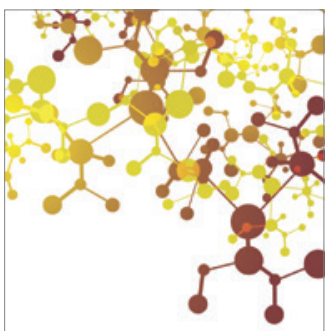

Journal of

Applied Chemistry

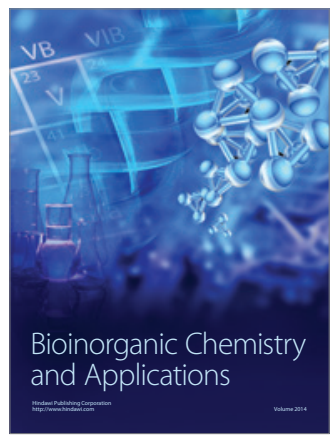

Inorganic Chemistry
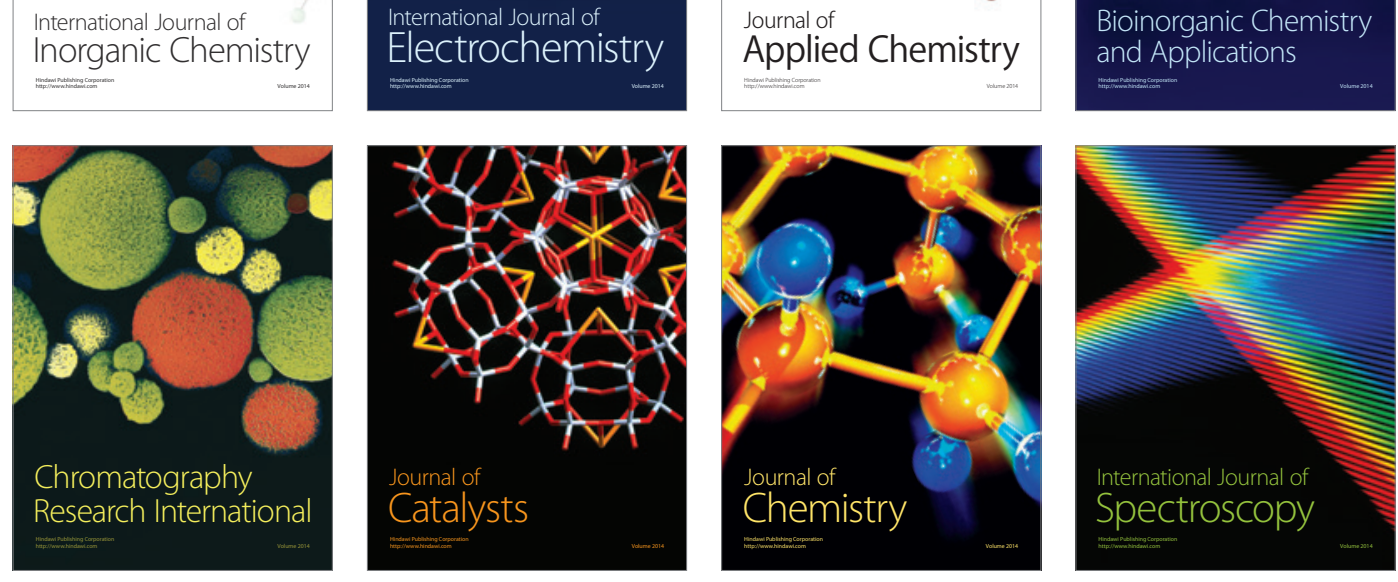